\title{
'n Verkenning van die verhouding tussen wetenskap en inheemse kennis: Moontlikhede vir integrasie in Suid-Afrikaanse Lewenswetenskappeklaskamers
}

\author{
Author: \\ Lesley le Grange ${ }^{1}$ \\ Affiliation: \\ ${ }^{1}$ Department of Curriculum \\ Studies, Stellenbosch \\ University, South Africa \\ Correspondence to: \\ Lesley le Grange \\ Email: \\ Ilg@sun.ac.za \\ Postal address: \\ Private Bag X1, Matieland \\ 7602 , South Africa \\ Dates: \\ Received: 30 May 2015 \\ Accepted: 21 July 2015 \\ Published: 14 Sept. 2015 \\ How to cite this article: \\ Le Grange, L., 2015, \\ "n Verkenning van die \\ verhouding tussen \\ wetenskap en inheemse \\ kennis: Moontlikhede \\ vir integrasie in Suid- \\ Afrikaanse Lewenswetens- \\ kappeklaskamers', \\ Suid-Afrikaanse Tydskrif \\ vir Natuurwetenskap en \\ Tegnologie 34(1), Art. \\ \#1338, 8 pages. http:// \\ dx.doi.org/10.4102/satnt. \\ v34i1.1338

\section{Copyright:} \\ C 2015. The Authors. \\ Licensee: AOSIS \\ OpenJournals. This work is \\ licensed under the Creative \\ Commons Attribution \\ License.
}

Read online:

Scan this QR code with your smart phone or mobile device to read online.
Die artikel is 'n teoretiese verkenning van die verhouding tussen wetenskap en inheemse kennis, sowel as die implikasies wat die integrasie van die twee beginsels in Lewenswetenskapklaskamers sal hê. Dié teoretiese bespreking gebruik insigte uit die sosiologie van wetenskaplike kennis en argumenteer dat die wetenskap nie net as voorstelling gesien moet word nie, maar ook as beoefening. Daar word aangevoer dat hierdie siening as die basis vir die integrasie van inheemse kennis in die Lewenswetenskappe kan dien. Praktiese voorstelle word gemaak oor hoe inheemse kennis in die Lewenswetenskapklaskamers verweef kan word en hoe onderwysers leerders kan lei deur die verskillende tipe of fases van wat Jegede, 'kollaterale leer' noem.

Exploring the relationship between science and indigenous knowledge: Possibilities for integration in South African Life Sciences classrooms. The article is a theoretical exploration of the relationship between science and indigenous knowledge, as well as the implications for integrating the two in Life Sciences classrooms in schools. The theoretical discussion draws on insights from the sociology of scientific knowledge and argues that science should not only be viewed as representation but also as performance. Such a view, it is argued, serves as the basis for integrating indigenous knowledge into the Life Sciences. Practical suggestions are made as to how indigenous knowledge could be infused into Life Sciences classrooms and how teachers can scaffold learners through different types or stages of what Jegede calls, 'collateral learning'.

\section{Inleiding}

Die verhouding tussen wetenskap en inheemse kennis het oor die afgelope drie dekades baie aandag geniet. Daar is verskeie redes daarvoor, wat ek kortliks sal uiteensit. Eerstens word die oorheersing van Westerse wetenskap bevraagteken deur, onder andere, postkolonialiste, antikolonialiste, filosowe van die wetenskap, feministe, sosioloë van kennis en poststrukturaliste. Sentraal in hierdie uitdaging is 'n oproep tot die demokratisering van die wetenskap sodat Westerse wetenskap gedesentraliseer, en inheemse kennis gedemarginaliseer kan word (Gough 1998; Harding 1993, 1994, 1998; Le Grange 2004). Tweedens het inheemse kennis internasionaal groter prominensie gekry nadat die Verenigde Nasies die tydperk 1995-2004 tot die Dekade van die wêreld se Inheemse Mense verklaar het. Hierdie tydperk is met 'n verdere dekade verleng (2005-2014). Derdens het die belangstelling in inheemse kennis gegroei vanweë die globale samelewing se oorgang van 'n industriële ekonomie na 'n kennisekonomie. 'n Voorbeeld hiervan is die aandag wat farmaseutiese maatskappye in etnobotaniese kennis toon. Oor hierdie ontwikkeling argumenteer Smith (2005:93) dat inheemse kennis wat aanvanklik ontken is deur die Westerse wetenskap en gesien is as irrasioneel en dogmaties, nou as een van die baanbrekers van kennis beskou word. Ons het byvoorbeeld die ontstaan van die vakgebied etnobotanie gesien wat omvat dat plantkundiges nou saam met inheemse gemeenskappe werk wat die versameling en dokumentasie van plante vir medisinale doeleindes betref. Etnobotanie sluit in die weg beweeg vanaf tradisionele wetenskaplike ondersoek na die implementering van kwalitatiewe navorsingsmetodes. Hierdie metodes behels, onder meer, onderhoude met gemeenskapsdeskundiges, die waarneming van praktyke en die ontwikkeling van woordbanke en ander hulpbronne (Smith 2005:94). Hierdie ontwikkeling kan aan die ander kant ook deur sommige inheemse gemeenskappe beskou word as 'n wettige manier om tot die hoofstroomekonomie en samelewing toe te tree en om uit die gemarginaliseerde omstandighede te beweeg waarin hulle hulself bevind. Ander redes vir'n groeiende belangstelling in die verhouding tussen wetenskap en inheemse kennis kan natuurlik aangevoer word, maar die drie redes wat genoem is, is voldoende vir die doeleindes van hierdie artikel. 'n Algemene verwondering oor die verhouding tussen 
wetenskap en inheemse kennis het die afgelope twee dekades belangstelling oor dié onderwerp in die wetenskaponderwys laat ontstaan, soos byvoorbeeld ' $n$ paar robuuste debatte in 'n spesiale uitgawe van die tydskrif Science Education, en ook artikels wat gevolg het op hierdie uitgawe (sien Carter 2004; Cobern \& Loving 2001; Siegel 2002; Snively \& Corsiglia 2001, 2005; Stanley \& Brickhouse 2001).

Suid-Afrika is nie onaangeraak gelaat deur hierdie ontwikkelings nie. Die land se oorgang na 'n demokrasie in 1994 het geleenthede gebied om blootstelling en erkenning te gee aan kennis wat tydens beide kolonialisme en apartheid gemarginaliseer is. Kort na die demokratisering in SA het die Afrika Renaissance begin. Met betrekking daartoe, het Odora Hoppers (2002) geskryf:

Die Afrika-Renaissance het dit ten doel om 'n dieper begrip van Afrika, sy taal en sy kennissisteme te ontwikkel. Dit is 'n projek wat die herskryf van die vernaamste leerstellings van die geskiedenis, in die verlede, asook in die hede, insluit. [Inheemse kennissisteme] IKS'e stel dus geweldige uitdagings aan die heropbou- en ontwikkelingstrategieë in Suid-Afrika. (bl. 2)

Prominensie wat aan inheemse kennis in Suid-Afrika gegee word, blyk duidelik uit konferensies wat gehou word oor dié onderwerp, die identifisering van Inheemse Kennissisteme (IKS'e) as een van die navorsingsfokusgebiede van die Nasionale Navorsingstigting en die ontstaan van 'n vaktydskrif, Indilinga: African Journal of Indigenous Knowledge Systems oor hierdie onderwerp. Hierdie ontwikkelings het na die skoolkurrikulum oorgespoel, soos bewys word deur die feit dat inheemse kennis op alle terreine deel van die postapartheid- nasionale kurrikulumraamwerk vorm. Dit word netjies vasgevang in die Nasionale Kurrikulumverklaring (NKV-dokument):

Now people recognise the wide diversity of knowledge systems through which people make sense of and attach meaning to the world in which they live. Indigenous knowledge systems in the South African context refer to a body of knowledge embedded in African philosophical thinking and social practices that have evolved over thousands of years. The National Curriculum Statement Grades 10-12 (General) has infused indigenous knowledge systems into the Subject Statements. [Nou word die omvangryke diversiteit van kennissisteme waardeur mense sin maak van en betekenis heg aan die wêreld waarin hulle leef, erken. Inheemse kennissisteme in die Suid-Afrikaanse konteks verwys na die beliggaming van kennis wat vasgelê is in die filosofiese denke en sosiale praktyke wat oor duisende jare ontwikkel het. Die Nasionale Kurrikulumverklaring Graad 10-12 (Algemeen) het inheemse kennissisteme geïntegreer in die Vakverklarings.] (Department of Education 2003:9, [outeur se eie vertaling])

Een van die sewe beginsels wat deur die mees onlangse weergawe van die NKV, die Kurrikulum en Assesseringsbeleidsverklaring (KABV) onderskryf word, is die belangrikheid van inheemse kennissisteme en dit lui soos volg:

Waardering vir inheemse kennissisteme: die erkenning van die ryk geskiedenis en erfenis van hierdie land as belangrike bydrae tot die kweek van die waardes soos dit in die Grondwet vervat word. (Geen bladsy)
Hierdie beginsel het implikasies vir alle vakke, insluitend die wetenskappe. Met betrekking tot laasgenoemde, ontstaan die vraag wat die verhouding tussen wetenskap en inheemse kennis is (of moontlik kan wees)? 'n Aantal onlangs gepubliseerde artikels oor dié onderwerp is 'n aanduiding van die erns waarmee Suid-Afrikaanse wetenskapopvoedkundiges hierdie vraag bejeën (sien byvoorbeeld, De Beer \& Mothwa 2013; Diwu \& Ogunniyi 2012; Nhalevilo 2013; Webb 2013).

Die prominensie wat internasionaal aan inheemse kennis gegee word, die uitdaging van die oorheersing van Westerse wetenskap en die insluiting van inheemse kennis as een van die beginsels waarop die Suid-Afrikaanse skoolkurrikulum gebaseer is, dien as agtergrond vir die verkenning van die verhouding tussen wetenskap en inheemse kennis, asook die implikasies daarvan vir die Lewenswetenskapkurrikulum in Suid-Afrika. Daar sal geargumenteer word dat die beskouing van wetenskap as beoefening die basis vir die integrasie van inheemse kennis en die wetenskap is. Die res van die artikel is in die volgende afdelings verdeel: die verhouding tussen wetenskap en inheemse kennis; 'n ontleding van die verhouding tussen wetenskap en inheemse kennis in die KABV vir Lewenswetenskappe; integrasie van die wetenskap en inheemse kennis in die Lewenswetenskapklaskamer deur die konsep van kollaterale leer. Vervolgens is daar 'n paar opsommende slotgedagtes.

\section{Die verhouding tussen wetenskap en inheemse kennis}

Daar is twee hoofoorwegings met betrekking tot die verhouding tussen wetenskap en inheemse kennis. Die eerste is 'n inklusiewe standpunt wat beweer dat die wetenskap multikultureel is. Multikulturaliste soos Stanley and Brickhouse (2001) en Snively and Corsiglia (2001) het 'n relativistiese, kontekstuele en historiese siening van die wetenskap (maar nie antirealisties nie) en gee erkenning daaraan dat die uiteenlopende wyses waarop verskillende kulture die natuurlike wêreld ervaar, ook as wetenskap beskou kan word. Die tweede is 'n universalistiese oorweging wat beweer dat die moderne Westerse wetenskap kennis produseer wat betroubaarder is en oor beter insig en begrip van die natuurlike wêreld as inheemse kennis beskik. Met betrekking tot hierdie standpunt wys Siegel (2002:805) daarop dat selfs al was inheemse kennis en tradisionele ekologiese kennis (TEK) suksesvol met die onthulling van belangrike kennis, is die moderne Westerse wetenskap meer suksesvol wat betref 'die ontdekking van die ware toetsbare, voorspellende en verklarende soort van wetenskaplike kennis waarop die Universaliste roem'. Vir 'n meer gedetailleerde bespreking oor die debat tussen universalisme en multikulturalisme in verhouding tot die wetenskap, sien Le Grange (2004). Die uitbeelding van die verhouding tussen wetenskap en inheemse kennis in die $\mathrm{KABV}$-dokument is nie duidelik belyn met enigeen van die standpunte nie. Dit maak egter duidelik dat inheemse kennis en wetenskap hul oorsprong in verskillende wêreldbeskouings het: 
Alle kennis ontstaan uit sienings oor hoe die wêreld werk. Een van die verskille tussen die moderne wetenskap (en tegnologie) en tradisionele, inheemse kennissisteme is dat hulle hul oorsprong in verskillende wêreldbeskouings het. (Geen bladsy)

Nietemin beweer Le Grange (2007) dat die Westerse wetenskap en inheemse kennis beskou kan word as óf uiteenlopende epistemologieë óf as aanvullende raamwerke. Dit hang daarvan af of die wetenskap as voorstelling (science as representation) of aan die ander kant as beoefening (science as performance) gesien word. Wetenskap as voorstelling verwys na wat kennis is - hoe dit voorgestel word, soos in handboeke, byvoorbeeld. Wetenskap as beoefening verwys na die gesitueerde proses van kennisproduksie hoe kennis geproduseer word. In sy insiggewende werk Die struktuur van wetenskaplike revolusies identifiseer Kuhn (1970) twee afsonderlike begrippe van die term paradigma, naamlik paradigma as dissiplinêre matriks en paradigma as voorbeeld. Eersgenoemde dui op die 'hele konstellasie van oortuigings, waardes, tegnieke, ensovoorts gedeel deur die lede van 'n gegewe gemeenskap' (Kuhn 1970:175). Laasgenoemde verwys na 'n soort element in daardie konstellasie:

... die konkrete oplossing van raaisels wat aangewend kan word as 'n model of voorbeeld om die eksplisiete reëls te vervang wat as die basis dien vir die oplossing van die oorblywende raaisels van normale wetenskap. (bl. 175)

Turnbull (2000:8) wys daarop dat Kuhn (1970) se eerste gebruik van die term paradigma (die hooffokus van sy boek) ietwat soortgelyk is aan 'n globale teorie, soos Newtoniaanse fisika, en onderhewig is aan revolusionêre verandering. Die tweede gebruik (voorbeeld/eksemplaar), aan die ander kant, is nader aan die standaardbetekenis van die term: "n voorbeeld/eksemplaar van probleemoplossing wat kan ekstrapoleer tot ander probleme' (Turnbull 2000:8). Voorbeelde/eksemplare is gegrond op eenstemmigheid oor watter soort probleme voldoende ooreenkomste toon sodat hulle op dieselfde manier behandel kan word. Die implikasie hiervan is dat uiteenlopende probleme as gelyksoortig beskou kan word en bekende tegnieke en oplossings aangewend kan word om hulle op te los. Turnbull (2000:8) wys daarop dat voorbeelde/eksemplare die produk is van vanselfsprekende kennis wat aangeleer is deur wetenskap te beoefen eerder as deur die verkryging van reëls vir die beoefening van wetenskap.

Om Kuhn aan te haal: '... die hele konstellasie van oortuigings, waardes, tegnieke, en so aan' wat gedeel word deur tradisionele Afrika- en Westerse gemeenskappe word as anders beskou. Om kennissisteme/wêreldbeskouings konseptueel te skei, help ons om te dink en te leer (d.w.s. vir heuristiese doeleindes). Die gevaar bestaan egter dat ons konstruksies/afbeeldings beskou kan word as spieëlbeelde van die werklikheid tot so 'n mate dat ons probeer om die werklikheid te laat aanpas by hierdie afbeeldings. Die outeur onthou byvoorbeeld dat toe hy as 'n universiteitstudent gevra is om voorwerpe wat hy waargeneem het met behulp van 'n ligmikroskoop te skets, hy (en sy mede-studente) dikwels die diagram van die voorwerp in die handboek geraadpleeg het om die akkuraatheid van sy werk te meet. As 'n student van die wetenskap het hy nie vertroue in sy eie waarneming gehad nie, maar het eerder gesteun op hoe akkuraat sy waarneming ooreenstem met die voorwerp(e) soos dit in 'n handboek verskyn. Skool- en universiteitstudente leer vroeg om die wetenskap as 'n voorstelling te sien en so word nagelaat om die wetenskap as beoefening te beskou. Wat studente nie leer nie, is dat betrokkenheid (jy moet as't ware jou hande vuil maak) by die wetenskap nodig is. Dit is immers noodsaaklik om by die ontdekking van alle vorme van kennis betrokke te wees. Verder word daar in voorstellings van Westerse en inheemse kennis uit Afrika dikwels voorgehou dat Westerse wetenskap meerderwaardig en universeel is. Daar word aangeneem dat Westerse kennis nie oor die 'kulturele vingerafdrukke' beskik wat veel opvallender in ander kennissisteme is nie (Gough 1998:508). Voorts word die Westerse wetenskap as kriteria gebruik om 'ander' kennis as niewetenskap te klassifiseer. Die perspektief van voorstaanders van voorgestelde kennis op daardie kennis, veroorsaak dus die siening dat simbiose nie moontlik is tussen Westerse wetenskap en inheemse kennis nie. Met ander woorde dat Westerse wetenskap en inheemse kennis onversoenbaar is, en dat inheemse kennis erken kan word as 'n besondere manier om die wêreld te beskou, maar dat dit nie 'n wetenskap in eie reg is nie.

Indien daar egter begrip is vir die produksie van kennis as beoefening, word dit moontlik om skynbaar uiteenlopende kennissisteme met mekaar te versoen sodat nuwe kennisruimtes geskep word. Turnbull (1997:560) bestempel hierdie kennisruimtes as 'derde ruimtes' of 'tussenruimtes'. Daar word algemeen deur sosioloë van wetenskaplike kennis en filosowe van die wetenskap erken dat, selfs al verskil kennissisteme ten opsigte van hul epistemologieë, metodologieë, logika, kognitiewe strukture of in hul sosioekonomiese kontekste, hulle steeds almal dieselfde eienskap van hul omgewing deel (kyk Latour 1988; Rouse 1987; Shapin 1994; Turnbull 1997, 2000). Bowenal is kennis nie bloot plaaslik nie, maar gesitueerd, met ander woorde dit het plek en dit skep ruimte. Wanneer kennis geproduseer word, word dit saamgestel uit heterogene komponente, en samehang word daaraan gegee deur die ontplooiing van sosiale strategieë en tegniese toerusting. Soos Star (1989) skryf:

Knowledge production is deeply heterogeneous: different viewpoints are constantly being adduced and reconciled ... Each actor, site, or node of a scientific community has a viewpoint, a partial truth consisting of local beliefs, local practices, local constants, and resources, none of which are fully verifiable across all sites. The aggregation of all viewpoints is the source of the robustness of science. [Die produksie van kennis is baie heterogeen: verskillende standpunte word voortdurend aangevoer en versoen ... Elke akteur, plek, of nodus van 'n wetenskaplike gemeenskap het ' $n$ standpunt, 'n gedeeltelike waarheid bestaande uit plaaslike oortuigings, plaaslike praktyke, plaaslike konstante en hulpbronne, waarvan geen op alle terreine ten volle gestaaf kan word nie. Die samevoeging van alle standpunte is die bron wat die robuustheid van die wetenskap tot gevolg het.] (bl. 388, [outeur se eie vertaling]) 
Die punt is dat kennisproduksie, selfs binne die Westerse tradisie, saamgestel is uit heterogene komponente. Die beskouing van wetenskap as beoefening gee erkenning aan hierdie feit. Wanneer wetenskap as voorstelling beskou word, gaan dié feit verlore en kennisproduksie word as 'n homogene proses voorgestel en verskillende kennissisteme word as uiteenlopend beskou. Soos reeds genoem, is die gemeenskaplike element van alle kennissisteme hul gesitueerdheid. Maar hul verskille lê in die manier waarop hulle saamgestel is 'deur middel van sosiale strategieë en tegniese vaardighede om ooreenkomste en verbindings te bewerkstellig tussen andersins heterogene en onversoenbare komponente' (Turnbull 2000:13). Soos Turnbull (1997) skryf:

Some traditions move it and assemble it through art, ceremony and ritual; [Western] science does it through forming disciplinary societies, building instruments, standardisation techniques and writing articles. In both cases, it is a process of knowledge assembly through making connections and negotiating equivalences between the heterogeneous components while simultaneously establishing a social order of trust and authority resulting in a knowledge space. [Sommige tradisies beweeg en verenig dit deur middel van kuns, seremonies en rituele; [Westerse] wetenskap doen dit deur die vorming van dissiplinêre gemeenskappe, die maak van instrumente, standaardiseringstegnieke en die skryf van artikels. In beide gevalle, is dit ' $n$ proses van die versameling van kennis deur ooreenkomste te tref en ooreenkomste te beding tussen heterogene komponente en terselfdertyd ' $n$ sosiale orde van vertroue en gesag te skep wat ' $n$ ruimte van kennis tot gevolg het.] (bl. 553, [outeur se eie vertaling])

Hierdie beskouing van kennis maak dit moontlik om skynbaar uiteenlopende kennistradisies te integreer en sodoende die tweespalt tussen Westerse wetenskap en inheemse kennis te ontwrig. Kortom, die wetenskap as voorstelling verwys na: abstraksies soos teorieë en wette; die idee van ' $n$ wetenskaplike metode; beskrywings van die wêreld in handboeke en dies meer. Wetenskap as beoefening, verwys egter na die doen van die wetenskap, dit is, dat die wetenskap 'n menslike, sosiale en selfs vuilerige aktiwiteit is wat heterogeen en gesitueerd is. Dit is die beskouing van wetenskap as beoefening wat die teoretiese begronding gee vir die integrasie van inheemse kennis en Westerse wetenskap binne die Lewenswetenskappe. Maar wat kan onderwysers doen om studente te help om die wetenskap en inheemse kennis te integreer en hoe word dit deur die KABV moontlik gemaak?

\section{Inheemse kennis in die Kurrikulum en Assesseringsbeleidsverklaring vir Lewenswetenskappe}

Die verwysings na inheemse kennis in die inleiding van die dokument vir Lewenswetenskappe in die KABV is belowend. Dit verklaar dat inheemse kennisstisteme een van die beginsels is waarop die KABV berus (Department of Basic Education [DBE] 2011:5). Een van die drie spesifieke doelwitte van die Lewenswetenskappe fokus op die verhouding tussen inheemse kennis en wetenskap (DBE 2011:13). Die belangrikheid om leerders bloot te stel aan die geskiedenis van die wetenskap en inheemse kennis word beklemtoon (DBE 2011:17), terwyl die verhouding tussen wetenskap en inheemse kennis noukeurig uiteengesit word (DBE 2011:17). Die belofte van die integrasie van inheemse kennis in die skoolkurrikulum vir Lewenswetenskappe word egter nie in die inhoud en inhoudspesifikasies van die dokument vir Lewenswetenskappe in die KABV weerspieël nie. Slegs twee verwysings na inheemse kennis word by die inhoudspesifikasies gemaak.

By die onderwerp Plant- en diereweefsel en die inhoudafdeling Toepassing van inheemse sisteme en biotegnologie, word die volgende gesê: ' ... tradisionele tegnologie, bv. tradisionele medisyne en genesers' (DBE 2011:28). Onder die onderwerp en inhoudafdeling Verlies van biodiversiteit word die volgende gesê: 'inheemse kennissisteme en die volhoubare gebruik van die omgewing, bv. duiwelsklou, rooibos, fynbos, die Afrika-aartappel (Hypoxis) en Hoodia' (DBE 2011:52). Alhoewel inheemse kennis hier ingesluit word, dui dit beslis op ' $n$ ernstige verwatering van die integrasie van inheemse kennis en Lewenswetenskappe. Wat baie duidelik is, is dat die skrywers van die KABV-dokument vir Lewenswetenskappe nie die geleenthede om inheemse kennis met Lewenswetenskappe as skoolvak te integreer, ernstig ondersoek het nie. Dit wil voorkom asof die skrywers net kosmeties geraak het aan inheemse kennis by die inhoudspesifikasies (twee gevalle) om sodoende te voldoen aan die stelling in die inleiding van die dokument. Hierdeur word die potensiële transformasie van die integrasie van inheemse kennis met Lewenswetenskappe gestuit. Verskeie geleenthede vir die toevoeging van inheemse kennis tot die Lewenswetenskappe is nie deur die skrywers van die Lewenswetenskapdokument in die KABV erken nie. So byvoorbeeld is daar onder die inhoudspesifikasie Voedselsekuriteit geen verwysing na inheemse kennis nie. Dít ondanks die feit dat daar 'n goeie voorbeeld is van hoe inheemse kennis gebruik is in droogtegeteisterde gebiede soos Zimbabwe. Deur die gebruik van plaaslike kennis was inheemse boere in Zimbabwe in staat om te reageer op die uitdagings van die droogte deur suksesvol gewasse wat bestand is teen die verandering van klimaatstoestande te kweek. Soos Shava et al. (2009) skryf:

In the cultivation of traditional crops, the prior knowledge and seed resources that community members brought with them was mobilised to build local community capacity to withstand environmental change. This local knowledge was therefore revived and sustained within the local communities. For example, Mrs Mberengwa recalled how in the past back in her original home area Gutu when there were drought conditions they would grow traditional drought resistant cereal crops like rukweza (finger millet, Eluisine coracana), mapfunde (sorghum, Sorghum bicolor) and mhunga (pearl millet, Pennisetum americanum) ... The cereals had early maturing varieties that had a short growing season as well as late maturing varieties that had long growing seasons. [By die verbouing van tradisionele gewasse, is die voorafkennis en saadhulpbronne wat lede van die gemeenskap met hulle gebring het, aangewend om die plaaslike gemeenskap se vermoë om die veranderinge in die omgewing te weerstaan, te bevorder. Hierdie plaaslike kennis is dus hernuwe en aangemoedig binne die plaaslike gemeenskappe. So onthou mev. Mberengwa byvoorbeeld hoe hulle in die verlede tydens droogtes in haar tuisland Gutu tradisionele droogtebestande gewasse verbou het soos 
rukweza (vingerbroodmanna, Eluisine coracana), mapfunde (sorghum, Sorghum bicolor) en mhunga (pêrelbroodmanna, Pennisetum americanum). Die graan het variëteite wat 'n kort groeiseisoen het sowel as gewasse wat langer geneem het om ryp te word en 'n langer groeiseisoen gehad het.] (bl. 225 [outeur se eie vertaling])

Verwysing na die genoemde voorbeeld toon dat die insluiting van inheemse kennis in die KABV vir Lewenswetenskappe ernstig beperk is wat moontlikhede vir die integrasie van inheemse kennis en Lewenswetenskappe stuit.

Hoewel die meeste onderwysers geneig is om die voorskrifte van die nasionale kurrikulum te volg en net op die voorgeskrewe inhoud te fokus, is daar onderwysers wat inheemse kennis by die Lewenswetenskapkurrikulum sal voeg. Dus word daar gefokus op 'n bespreking oor hoe onderwysers die integrasie van inheemse kennis in die Lewenswetenskapklaskamer kan bewerkstellig. Om dit te kan aanleer, is dit dalk belangrik om eers te verstaan hoe inheemse leerders Westerse wetenskap leer.

\section{Integrasie van wetenskap en inheemse kennis in die Lewenswetenskapklaskamer}

In elke gemeenskap is daar interaksie tussen verskillende wêreldbeskouings, byvoorbeeld die kennis wat kinders deur godsdiens opdoen. Dit sal moontlik verskil van wat hulle in skoolwetenskap leer. Vir leerders van inheemse gemeenskappe is interaksie tussen twee wêreldbeskouings kenmerkend van hul skoolervaring. Dit bemoeilik die leerproses en kan lei tot kognitiewe konflik of soos die literatuur beskryf dit as kognitiewe dissonansie of steuring. In Afrika is skole die plek waar die meeste leerders vir die eerste keer die interaksie tussen inheemse en Westerse wêreldbeskouings ervaar. Dit is dus noodsaaklik dat onderwysers wat in hierdie omgewings werk (veral Westerse onderwysers) bewus sal wees van hierdie interaksie en sal verstaan hoe dit die leerproses bemoeilik. Jegede (1999:119) voer aan dat die kultuur van 'n leerder se onmiddellike omgewing ' $n$ belangrike rol in die leerproses speel en dat dit bepaal hoe konsepte geleer en as skemata in die langtermyngeheue gestoor word.

Le Grange (2007) wys daarop dat baie geskryf is oor problematiese aspekte by inheemse studente met die leer van wetenskap. 'n Opsomming van die belangrikste bevindings van gepubliseerde navorsing oor hoe inheemse leerders die wetenskap leer, toon dat:

- Sosio-kulturele agtergrond 'n groter uitwerking op leer het as vakinhoud;

- Die inheemse wêreldbeskouing inhibeer die anvanklike aanvaarding van Westerse wetenskap deur leerders;

- Inheemse (nie-Westerse) leerders is onwillekeurig selektief wanneer waarnemings in die wetenskapklaskamer gemaak word;

- Die inheemse leerder kan natuurverskynsels moontlik op 'n wyse verklaar wat in die persepsie van Westerse wetenskap as nie-rasioneel voorkom, maar die leerders ervaar geen teenstrydighede in hul konseptuele raamwerk nie;

- Kennis wat opgedoen is in skoolwetenskap en tradisionele kennis word deur die leerder in kompartemente geplaas en dit gee aanleiding tot wat Wiredu (1980:23) "n soort van etniese skisofrenie' noem. (Le Grange 2007, aangepas uit Jegede 1999:128)

Jegede (1999:128-129) identifiseer twee belangrike implikasies van hierdie bevindinge. Eerstens, enige wetenskapkurrikulum wat nie noukeurig rekening hou met die inheemse wêreldbeskouing van die leerder nie, loop die gevaar om die raamwerk waardeur die leerder begrippe interpreteer te beskadig. Tweedens, kan 'n inheemse leerder uitstekend presteer in 'n Westerse wetenskapklaskamer sonder om die gepaardgaande waardes te assimileer. Soos Jegede (1999:129) skryf: '['n] "goeie" wetenskaplike by die skool kan by die huis'n tradisionalis wees sonder enige gevoel van kognitiewe storing of dissonansie'. Laasgenoemde word belig in Jegede se teorie van kollaterale leer wat volgende bespreek word.

Jegede (1995) en Jegede (1999) voer aan dat 'n dualiteit in denke geskep is in die geheue en skemata van inheemse leerders wanneer hulle Westerse wetenskap leer, vanweë die veerkragtigheid van die inheemse kennisraamwerk. Dit is ook 'n manier om die vyandigheid teenoor die inheemse kennis wat leerders na die wetenskapklaskamer bring, te hanteer. Hy redeneer dat hierdie situasie kollaterale leer tot gevolg het. In hierdie konteks verwys kollaterale leer na hoe leerders Westerse wetenskap leer in interaksie met inheemse konsepte. Jegede (1999:133) identifiseer vier tipe kollaterale leer: parallelle, gelyktydige, afhanklike en beveiligde leer. Dit is belangrik dat hierdie tipe kollaterale leer nie beskou moet word as uiteenlopend nie, maar eerder as aaneenlopend, en dat ' $n$ student gehelp kan word om van die een na die ander te vorder sodat sinvolle leer kan plaasvind (Jegede 1999).

\section{Parallelle kollaterale leer}

Parallelle kollaterale leer vind plaas wanneer leerders teenstellende skemata oor 'n konsep en idee in hul langtermyngeheue verwerf en behou wanneer hulle nuwe wetenskapbeginsels aanleer. Die leerder ervaar nie konseptuele konflik nie, maar pas die geheue aan om veranderende kontekste van leer te akkommodeer. Jegede (1999:134) skryf dat parallelle leer veral duidelik is wanneer inheemse leerders vir die eerste keer in aanraking kom met skoolwetenskap en dat die naasbestaan van die nuwe inligting deur hierdie leerders in hul skemata toegelaat word terwyl hulle nog poog om sin daarvan te maak.

\section{Gelyktydige kollaterale leer}

Jegede (1999:134) wys daarop dat indien 'n konsep vasgelê moet word in die langtermyngeheue van 'n leerder, die inligting oor 'n lang tydperk verwerk moet word. Teen die tyd wanneer leerders dus blootgestel word aan 'n nuwe konsep in die wetenskapklaskamer is hulle moontlik steeds 
besig met die verwerking van inligting wat hulle geleer het by die huis of in hul kulturele omgewing in verband met hierdie konsep. 'n Situasie ontstaan wanneer leerders gelyktydig leer oor 'n konsep vanuit twee verskillende wêreldbeskouings. Gelyktydige kollaterale leer plaas leerders dus in 'n posisie om ooreenkomste en verskille tussen idees uit verskillende wêreldbeskouings te evalueer met betrekking tot die konsep wat geleer is.

\section{Afhanklike kollaterale leer}

Afhanklike kollaterale leer vind plaas wanneer skemata van een wêreldbeskouing aangebied word, wat dié van 'n ander wêreldbeskouing uitdaag en so die leerder in staat stel om bestaande skemata aan te pas. Geen radikale herstrukturering van die bestaande kennisbasis vind plaas nie, maar die aanleer van 'n nuwe idee word aangehelp deur wat reeds bekend is. Jegede (1999) skryf:

Dit beteken dat 'n bestaande oortuiging (inheemse of andersins) voorlopig behou word, maar verander word deur die konstruksie van nuwe kennis van die nuwe skemata of die verwerping van 'n bestaande een. (bl. 134)

\section{Beveiligde kollaterale leer}

Die verkryging van kennis of ' $n$ intellektuele vaardigheid is 'n geleidelike en inkrementele proses eerder as 'n enkele gebeurtenis. Om te verseker dat hierdie langdurige proses van leer effektief is, moet die leerders, wat hulle as kognitiewe konflik of geestelike dissonansie ervaar in die kennisbasis wat in hul langtermyngeheue ingebed is, oplos. Met ander woorde, die inheemse leerders moet die geestelike konflik verwerk, geskep deur die Westerse wetenskap wat hulle geleer het en die inheemse kennis wat hulle na die klaskamer gebring het. Die proses om die kognitiewe dissonansie te verwerk, kulmineer in die evaluering deur die leerder van skynbaar uiteenlopende raamwerke, gevolg deur die 'vorming van 'n samevloeiing van gemeenskaplikhede' (Jegede 1999:135). Hy skryf: 'Dit versterk die leerproses en beveilig die "nuwe opvatting" in die langtermyngeheue' (Jegede 1999:135).

Jegede (1999) se bevindings oor kollaterale leer bied nuttige insigte oor hoe inheemse studente Westerse wetenskap leer. Dit het belangrike implikasies vir die werk van onderwysers en onderwysersopleidingsprogramme. Eerstens moet onderwysers verstaan hoe belangrik dit is om nie die inheemse kennis wat leerders na die klaskamer bring, af te kraak of te diskrediteer nie, want dit dien as die raamwerk waarbinne hulle wetenskap leer en bied ook die sneller om wetenskap te leer. Tweedens verskaf die vier tipes kollaterale leer aan onderwysers ' $n$ raamwerk om inheemse leerders te bemagtig en te ondersteun deur die verskillende fases van die aanleer van die wetenskap. Wat belangrik is, is dat die KABV vaardighede (alhoewel beperk) voorstaan vir die fasilitering van prosesse om kollaterale leer te verseker, aangesien inheemse kennissisteme deel uitmaak van die inhoude van alle leerskoolvakke.
Die beskouing van wetenskap as beoefening dien as die teoretiese basis vir beveiligde kollaterale leer, en sonder laasgenoemde is die integrasie van inheemse kennis en Westerse wetenskap ingekort. Die integrasie van inheemse kennis en Lewenswetenskappe verlang van onderwysers om klem te plaas op die beoefening van die wetenskap en om nie net inligting soos voorgestel in handboeke aan leerders oor te dra nie. Maar hoe kan leerders ondersteun word om inheemse kennis en Westerse wetenskap te integreer? Jegede en Aikenhead (1999:55) stel voor dat onderwysers die rol van kulturele agente moet aanneem, met ander woorde hulle moet die leerders help bemagtig om kulturele grense oor te steek. Hulle stel voor dat die onderwyser in sommige gevalle as kulturele agent ' $n$ toergids moet wees en in ander gevalle as kulturele agent soos 'n reisagent optree. Wanneer dit vir die leerder moeilik is om kulturele grense (van leefwêreldkultuur na skoolwetenskapkultuur) oor te steek, moet die onderwyser die rol van 'n toergids vervul en die leerders na die sleutelplekke in die kultuur van wetenskap begelei en hulle afrig om te let op wat belangrik is en hoe om dit in hul alledaagse bestaan te gebruik. Om dit te doen, gebruik die onderwyser ' $n$ uitgebreide repertoire van metodes. In ander gevalle waar leerders minder leiding vereis om grense oor te steek, kan die onderwyser die rol van reisagent aanneem en sodoende aansporings soos besprekingspunte, kwessies, aktiwiteite of gebeure voorsien wat die behoefte skep om die kultuur van die wetenskap te verstaan. Met ander woorde, die oorsteek van grense word moontlik gemaak deur akademiese brûe en nie soseer deur begeleiding nie. Om leerders deur parallelle en gelyktydige kollaterale leer te ondersteun, sal beteken dat die onderwyser die rol van die toergids moet aanneem, terwyl om ondersteuning aan leerders deur of van afhanklike leer na beveiligde kollaterale leer te gee, kan dit vir die onderwyser nodig wees om hoofsaaklik die rol van die reisagent aan te neem. Nodeloos om te sê, beide benaderings aanvaar dat leer of onderrig binne 'n ekokulturele paradigma plaasvind, met ander woorde dat die wetenskapinhoud wat in klaskamers geleer word, 'n noue verband hou met en gebruik maak van die leefwêreld van die leerder as die fokus- en vertrekpunt van leer. Verder is beide benaderings afhanklik van interaktiewe onderrigstrategieë en beskouing van wetenskap as beoefening. Twee interaktiewe strategieë sal nou by wyse van illustrasie bespreek word.

In Suid-Afrikaanse klaskamers ervaar leerders kognitiewe dissonansie tydens leer oor sekere verskynsels in die wetenskapklaskamers. Die wetenskaplike perspektief dat weerlig veroorsaak word deur die vrystelling van elektrisiteit tussen die wolke of uit 'n wolk na die aarde, is byvoorbeeld in stryd met die kulturele leerders se begrip dat weerlig veroorsaak word deur heksery. Twee strategieë kan nuttig gebruik word om leerders in hierdie geval te help om kognitiewe storing te hanteer. Die eerste strategie is wat Bajracharya en Brouwer (1997:436) bestempel as "n narratiewe benadering'. Hierdie benadering behels die plasing van leerders in klein groepbesprekings oor vrae soos: 'Word weerlig veroorsaak deur toordery?' Wat 
hierdie benadering doen, is om in 'n mate 'n konseptuele ekokulturele paradigma te voorsien wat as basis kan dien vir die onderwyser om die rol van kulturele agent oor te neem. Die tweede benadering is die een wat ingevoer is deur Aikenhead (1996), waar die oorsteek van grense konkreet gemaak is deur te vra dat leerders die bladsy in hul notaboek in die helfte verdeel in twee kolomme: 'my idees' en die 'idees van die wetenskapkultuur'. Hierdie strategie of aktiwiteit stel die leerder in staat om bewustelik heen en weer tussen die inheemse wêreld en die wêreld van die wetenskap te beweeg terwyl: 'terminologie duidelik geruil word, taalraamwerke en konvensies duidelik geruil word, begrippe duidelik geruil word' (Jegede \& Aikenhead 1999:57). Die onderwyser is in staat om leerders se bevindinge te evalueer en tussen die verskillende rolle van toergids en reisagent te beweeg om sodoende leerders se oorsteek van grense te fasiliteer.

Maar, laat ons kyk na 'n voorbeeld wat ingesluit is in die KABV-dokument vir Lewenswetenskappe. Die eerste voorbeeld hou verband met tradisionele medisyne en genesing. Die benadering van Snively en Corsiglia (2001:27) wat uit vyf stappe bestaan, sal aangepas moet word om te wys hoe 'n onderrig/leer-eenheid ontwikkel kan word om die wetenskap en inheemse kennis ten opsigte van medisyne en genesing met mekaar te integreer.

Die eerste is om 'n interessante onderwerp te kies. In hierdie geval kan die onderwyser saam met leerders oor 'n onderwerp soos medisyne wat gebruik word vir hoofpyn of verkoue of artritis, ensovoorts besluit.

Die tweede stap is om persoonlike kennis te identifiseer. Dit sluit respek vir ander se oortuigings in, 'n dinkskrum om uit te vind wat elke leerder weet oor medisyne wat gebruik word om hoofpyn te genees, 'n dinkskrum oor vrae oor die onderwerp en elke leerder wat hul eie persoonlike, idees en oortuigings oor die onderwerp identifiseer.

Die derde stap is om die verskillende perspektiewe te ondersoek. Dit behels navorsing oor die perspektief van die moderne Westerse wetenskap oor die behandeling van hoofpyn, sowel as die inheemse perspektief oor watter medisyne tradisionele genesers gebruik, ensovoorts. Leerders sal die inligting organiseer en verwerk en ooreenkomste en verskille tussen die twee perspektiewe identifiseer.

Die vierde stap is refleksie. In hierdie stap sal die leerders die gevolge van elke perspektief bedink, die moontlikheid van 'n sintese van perspektiewe bedink, die proses van verskillende standpunte bedink, die moontlikheid van 'n gedeelde visie bedink.

Die vyfde stap is die evaluering van die proses. Dit behels die evaluering van die besluitnemingsproses en om leerders ' $n$ kans te gee om hul mening oor die proses uit te spreek. Die proses wat beskryf is, is gegrond op die respek wat onderwysers toon vir die kennis wat leerders na die klaskamer bring en die gebruik daarvan as beginpunt in die pedagogiese episode. Die proses kan leerders deur Jegede se tipe van kollaterale leer neem vanaf parallelle leer tot beveiligde leer.

\section{Slot}

Die integrasie van die wetenskap en inheemse kennis in die wetenskapkurrikula van die skool het die laaste twee dekades veel aandag in die literatuur oor wetenskaponderrig ontvang. Die onderwerp is ' $n$ kontroversiële saak wat gesentreer het om die vraag of die wetenskap universeel of multikultureel is (kyk Le Grange 2004 vir 'n volledige bespreking). Die debat het grootliks gefokus op wat wetenskap is en wat inheemse kennis is, met verwysing na die wetenskap as verteenwoordiging of voorstelling. In hierdie artikel is daar egter geredeneer dat die beskouing van wetenskap as beoefening dit moontlik maak om te identifiseer wat die produksie van wetenskaplike kennis gemeen het met alle kennissisteme, dat alle kennissisteme gesitueerd is - hulle verenig mense, plekke en vaardighede - en dat die grondslag van die produksie van kennis die vertroue van die sosiale organisasie is. Die beskouing van wetenskap as beoefening maak dit moontlik om ' $n$ regverdige vergelyking te tref tussen Westerse wetenskap en ander kennissisteme en so as die basis te dien vir die Westerse wetenskap en inheemse kennis om saam te werk in nuwe kennisruimtes, bekend as 'n derde ruimte of tussenruimtes. Die regverdige vergelyking tussen moderne Westerse wetenskap en inheemse kennis vorm 'n goeie basis vir die integrasie van die twee in skoolwetenskap.

Kurrikulumbeleid verplig die insluiting van inheemse kennis in alle skoolvakke in Suid-Afrika, insluitend die Lewenswetenskappe. Daar is egter reeds getoon dat die integrasie van inheemse kennis in die KABV vir Lewenswetenskappe afgewater is en dat slegs twee verwysings na inheemse kennis gemaak is in die inhoudspesifikasies. Die artikel wys daarop dat onderwysers wat hul leerders ken en respekteer, maniere sal vind om inheemse kennis in die leerprogramme van Lewenswetenskappe te integreer in multikulturele klaskamers. Die outeur beskryf 'n paar praktiese strategieë waarop onderwysers inheemse kennis in Lewenswetenskapprogramme kan insluit (met behulp van medisyne wat hoofpyn kan behandel as voorbeeld) en hoe dit leerders kan help om deur Jegede se tipe van kollaterale leer te beweeg.

\section{Erkenning Mededingende belange}

Die outeur verklaar dat hy geen finansiële of persoonlike verhouding(s) het wat hom op 'n voordelige of nadelige wyse in die skryf van die artikel beïnvloed het nie.

\section{Literatuurverwysings}

Aikenhead, G.S., 1996, 'Science education: Border crossing into the subculture of science', Studies in Science Education 27, 1-52. http://dx.doi.org/10.1080/ 03057269608560077

Bajracharya, H. \& Brouwer, W., 1997, 'A narrative approach to science teaching in Nepal', International Journal of Science Education 19, 429-446. http://dx.doi. org/10.1080/0950069970190406 
Carter, L., 2004, 'Thinking differently about cultural diversity: Using postcolonial theory to (re)read science education', Science Education 88, 819-836. http:// theory to (re)read science ed
dx.doi.org/10.1002/sce.20000

Cobern, W. \& Loving, C., 2001, 'Defining "science" multicultural world: Implications for science education', Science Education 85, 50-67. http://dx.doi.org/10.1002/1098237X(200101)85:1<50::AID-SCE5>3.0.CO;2-G

De Beer, J. \& Mothwa, M., 2013, 'Indigenous knowledge in the science classroom Science, pseudo-science, or a missing link?' paper presented at the ISTE International Conference on Mathematics, Science and Technology Education, Kruger National Park, 21-24 October.

Department of Basic Education (DBE), 2011, Curriculum and assessment policy statement, Grades 10-12: Life Sciences, Department of Basic Education, Pretoria.

Department of Education (DoE), 2003, National curriculum statement Grades 10-12 (general), Life Sciences, Department of Education, Pretoria.

Diwu, C.T. \& Ogunniyi, M.B., 2012, 'Dialogical argumentation instruction as a catalytic agent for the integration of school science with indigenous knowledge systems', African Journal of Research in Mathematics, Science and Technology Education 16(3), 333-347. http://dx.doi.org/10.1080/10288457.2012.10740749

Gough, N., 1998, 'All around the World: Science education, constructivism, and globalisation', Education Policy 12(5), 507-524. http://dx.doi.org/10.1007/978-1globalisation', Educ

Harding, S. (ed.), 1993, The 'racial' economy of science: Towards a democratic future, Indiana University Press, Bloomington.

Harding, S., 1994, 'Is science multicultural? Challenges, resources, opportunities, uncertainties', Configuration 2, 301-330. http://dx.doi.org/10.1353/con.1994. 0019

Harding, S., 1998, Is science multicultural? Postcolonialisms, feminisms, and epistemologies, Indiana University Press, Bloomington.

Jegede, O.J., 1995, 'Collaborative learning and the ecocultural paradigm in science and mathematics education in Africa', Studies in Science Education 25, 97-137.

Jegede, O.J., 1999, 'Science education in nonwestern cultures: Towards a theory of collateral learning', in L. Semali \& J. Kincheloe (eds.), What is indigenous
knowledge? Voices from the academy, pp. 119-142, Falmer Press, New York.

Jegede, O.J. \& Aikenhead, G.S., 1999, 'Transcending cultural borders: Implications for science teaching', Research in Science and Technological Education 17(1), 45-66. $\mathrm{http}: / /$ dx.doi.org/10.1080/0263514990170104

Kuhn, T., 1970, The structure of scientific revolutions, University of Chicago Press, Chicago.

Latour, B., 1988, The pasteurisation of France, Harvard University Press, Cambridge.

Le Grange, L., 2004, "Multicultural” science in South Africa's national curriculum statement', Africa Education Review 1(2), 204-219. http://dx.doi.org/10.1080/ 18146620408566280
Le Grange, L., 2007, 'Integrating western and indigenous knowledge systems: The basis for effective science education in South Africa?' International Review of Education 53(5-6), 577-591. http://dx.doi.org/10.1007/s11159-007-9056-x

Nhalevilo, E.A., 2013, 'Rethinking the history of inclusion of IKS in school curricula: Endeavouring to legitimate the subject', International Journal of Science and Mathematics Education 11(2), 23-42. http://dx.doi.org/10.1007/s10763-0129382-8

Odora Hoppers, C., 2002, 'Indigenous knowledge and the integration of knowledge systems', in C. Odora Hoppers (ed.), Towards a philosophy of articulation, pp. 2-20, NAE, Johannesburg.

Rouse, J., 1987, Knowledge and power: Towards a political philosophy of science, Cornell University Press, Ithaca.

Shapin, S., 1994, A social history of truth: Civility and science in 17th century England, University of Chicago Press, Chicago.

Shava, S., Zazu, C., Tidball, K. \& O'Donoghue, R., 2009, 'Local knowledge as a source of community resilience', Indilinga $8(2), 218-229$.

Siegel, H., 2002, 'Multiculturalism, universalism and science education', Science Education 86, 803-820. http://dx.doi.org/10.1002/sce.1052

Smith, L., 2005, 'On tricky ground: Researching the native in the age of uncertainty', in N. Denzin \& Y. Lincoln (eds.), The Sage handbook of qualitative research, 3rd edn., pp. 85-107, Sage publications, Thousand Oaks.

Snively, G. \& Corsiglia, J., 2001, 'Discovering indigenous science: Implications for science education', Science Education, 85, 6-34. http://dx.doi.org/10.1002/1098237X(200101)85:1<6::AID-SCE3>3.3.CO;2-1

Snively, G. \& Corsiglia, J., 2005, 'Response to Carter's postmodern, postcolonial analysis of Snively and Corsiglia's (2000) article "Discovering science",', Science Education 89, 907-912. http://dx.doi.org/10.1002/sce.20102

Stanley, W. \& Brickhouse, N., 2001, 'Teaching sciences: The multicultural question revisited', Science Education 85, 35-49. http://dx.doi.org/10.1002/1098 237X(200101)85:1<35::AID-SCE4>3.0.CO;2-6

Star, S., 1989, 'The structure of ill-structured solutions: Boundary objects and heterogeneous distributed problem solving', in L. Gasse \& M. Huhns (eds.), Distributed artificial intelligence, pp. 37-54, Morgan Kauffman Publications, New Distribut

Turnbull, D., 1997, 'Reframing science and other local knowledge traditions', Futures 29(6), 551-562. http://dx.doi.org/10.1016/S0016-3287(97)00030-X

Turnbull, D., 2000, Masons, tricksters and cartographers: Comparative studies in the sociology of scientific and indigenous knowledge, Routledge, London, New York.

Webb, P., 2013, 'Xhosa indigenous knowledge: Stakeholder awareness, value and choice', International Journal of Science and Mathematics Education 11(1), 89-110. http://dx.doi.org/10.1007/s10763-012-9370-z

Wiredu, K., 1980, Philosophy and an African culture, Cambridge University Press, Cambridge. 